\title{
CHEMICAL ANALYSIS AND COMPARISON OF ORDINARY PORTLAND CEMENT OF KHYBER PAKHTOON KHWA PAKISTAN
}

\author{
Noor-ul-Amin ${ }^{* 1}$, Khurshid Ali ${ }^{2}$ \\ ${ }^{1}$ Department of Chemistry, Abdul Wali khan University Mardan, Pakistan \\ ${ }^{2}$ Institute of Chemical Sciences University of Peshawar, Pakistan
}

Received 1 February 2010; received in revised form 17 May 2010

\begin{abstract}
In this study different brands of Ordinary Portland Cement (OPC) produced and available in Khyber Pakhtoon Khwa, Pakistan have been studied for different chemical parameters and compared with British standard specifications. The amounts of chemical constituents like $\mathrm{SiO}_{2}, \mathrm{Al}_{2} \mathrm{O}_{3}, \mathrm{Fe}_{2} \mathrm{O}_{3}, \mathrm{CaO}, \mathrm{MgO}, \mathrm{SO}_{3}$, insoluble residue (IR), free lime and loss on ignition (LOI) were determined in accordance with British Standard (BS) Specifications. All the results are presented to provide both quantitative and qualitative notion of several locally produced ordinary Portland cement. The composition of most of this constituents as determined experimentally were within the range of the standard values. The possible reasons for variation in chemical compositions and their consequences have been discussed.
\end{abstract}

Keywords: Ordinary Portland cement, Chemical Composition, Quality Verification

DOI:10.3329/cerb.v14i1.4320

\section{Introduction}

Every year Pakistan produces sufficient amount of ordinary Portland cement and utilizes in different projects for the construction of building, roads and highways etc. The use of low quality cement in structural and constructional works may cause loss of lives and properties. So, the quality assurance of cement is therefore becoming an important and critical factor. The cement to be used in construction projects must have certain qualities in order to play its part effectively in structure. When these properties lie within a certain specified range of standard values, the engineers are therefore more confident of satisfactory performance of cement. Moreover, based on these properties it is possible to compare the quality of cement from different sources. A number of tests are performed in the laboratories of cement industries to ensure that the cement is of the desired quality and it conforms to the requirement of the relevant standards [1-3].

It has been observed and reported that many buildings, are deteriorated very soon due to low quality of cement. After some time cement plaster on the walls especially from those areas which are in contact with ground in water logging areas, corrode due to the poor binding forces of the cement. In order to know the reasons, it was decided to study the quality of cement available in the local markets especially, those cements produced in Khyber Pakhtoon Khwa and compare with international standard to find out the possible causes of deteriorations.

There are twenty-seven cement plants in Pakistan [4, 5]. Out of which six are in the Khyber Pakhtoon Khwa namely Cherat Cement Company Limited Nowshera, Lucky Cement Limited, Kohat Cement Company Limited, Askary Cement Limited Nizampur (Army welfare trust), Bestway Cement

*Corresponding author, Email:noorulamin_xyz@yahoo.com
Company Limited and Mustehkam Cement. The annual production of the cement at the Khyber Pakhtoon Khwa along with their location is given in Table 1.

\begin{tabular}{|c|c|c|}
\hline Name of cement plant & Location & Annual production (Tons) \\
\hline Askary cement & Nizampur & 660000 \\
\hline Bestway Cement & Haripur & 900000 \\
\hline Cherat Cement & Lakarai & 759000 \\
\hline Kohat Cement & Babri banda & 330000 \\
\hline Lucky Cement & Pezu & 1320000 \\
\hline Mustehkam Cement & Hattar & 660000 \\
\hline Total production & & 4629000 \\
\hline
\end{tabular}

All the above cements are available in the local market. Their chemical compositions are almost the same with a little variation in elemental percentages. Variations in physical properties occur due to the variation in the amount of chemical constituents. The study was aimed to conduct chemical analysis of OPC produced in Khyber Pakhtoon Khwa and their comparison with British Standards. The chemical constituents studied are $\mathrm{SiO}_{2}, \mathrm{Al}_{2} \mathrm{O}_{3}, \mathrm{Fe}_{2} \mathrm{O}_{3}, \mathrm{CaO}, \mathrm{MgO}, \mathrm{SO}_{3}$, Insoluble residue (IR), free lime and loss on ignition (LOI).

\section{Chemistry of Ordinary Portland Cement}

During calcinations of raw material in the cement plant, the volume of material contracts and during hydration of cement it swells. Two possible reactions take place [6].

$$
\begin{aligned}
& \text { Calcinations: } \mathrm{CaCO}_{3}(\mathrm{~s}) \rightarrow \mathrm{CaO}(\mathrm{s})+\mathrm{CO}_{2}(\mathrm{~g}) \\
& \text { Hydration: } \mathrm{CaO}(\mathrm{s})+\mathrm{H}_{2} \mathrm{O}(\mathrm{l}) \rightarrow \mathrm{Ca}(\mathrm{OH})_{2}(\mathrm{~s})
\end{aligned}
$$

The raw materials used for the manufacture of Portland cement consist mainly of lime, silica, alumina and iron oxide. These compounds interact with each other in the kiln to form a series of more complex products, and apart from a 
small residue of uncombined lime, which has not had sufficient time to react; a state of chemical equilibrium is reached. Chemical components in Portland cement are combined to from different potential compounds. The amounts of these potential compounds are responsible for various physical properties of Portland cement.

During the formation of cement clinker, heat is absorbed in some processes while in the other heat is evolved. Evaporation of free water at $100^{\circ} \mathrm{C}$ requires $538 \mathrm{cal} / \mathrm{g}$. The heat absorbed in the dehydration of kaolin at $20^{\circ} \mathrm{C}$ is $168 \mathrm{cal} / \mathrm{g}$. In the case of montmorillonite the corresponding values are 58.5 and $94.6 \mathrm{cal} / \mathrm{g}$. The product of dehydration shows an exothermic reaction at about $900-950^{\circ} \mathrm{C}$ arising from the crystallization of the amorphous material and amounting in the case of kaolin to $72 \pm 10 \mathrm{cal} / \mathrm{g}$ dehydrated kaolin. The heat absorbed in dissociation of calcium carbonate is $422 \mathrm{cal} / \mathrm{g}$ at $20^{\circ} \mathrm{C}$ and $393 \mathrm{cal} / \mathrm{g}$ at $890^{\circ} \mathrm{C}$. For magnesium carbonate the values found by different investigations vary from 284-324 $\mathrm{cal} / \mathrm{g}$ at $20^{\circ} \mathrm{C}$ and $250-290 \mathrm{cal} / \mathrm{g}$ at $590^{\circ} \mathrm{C}$. The reaction of the dehydrated clay products with lime is associated with a considerable evolution of heat, which varies with the cement composition and raw materials, but only about $50-70 \mathrm{cal} / \mathrm{g}$ when slag and limestone are used. A heat evolution of 100 $\mathrm{cal} / \mathrm{g}$ is sufficient theoretically to raise the temperature of the reacting masses by over $300^{\circ} \mathrm{C}$ [6].

Four major compounds in Portland cement are $\mathrm{C}_{2} \mathrm{~S}, \mathrm{C}_{3} \mathrm{~S}$, $\mathrm{C}_{3} \mathrm{~A}$, and $\mathrm{C}_{4} \mathrm{AF}$. The silicates, $\mathrm{C}_{3} \mathrm{~S}$ and $\mathrm{C}_{2} \mathrm{~S}$, are the most important compounds, which are responsible for the strength of hydrated cement paste. The presence of $\mathrm{C}_{3} \mathrm{~A}$ in cement is undesirable. $\mathrm{C} 4 \mathrm{AF}$ is also present in cement in small quantities, and, compared with the other three it does not affect the behavior of the cement significantly [6].

\section{Experimental}

Cement samples were collected from local market of the six cement plants namely Cherat Cement, Askary cement, Bestway Cement, Kohat Cement, Lucky Cement and Mustehkam Cement. Samples were collected in polyethylene bags and carried to the laboratory for study. For each brand of cement three samples were collected from different stores on different dates and each sample was about one kilogram. The testing procedures based on British Standards [7] have been followed for chemical analysis of Portland cement. $\mathrm{SiO}_{2}, \mathrm{Al}_{2} \mathrm{O}_{3}, \mathrm{Fe}_{2} \mathrm{O}_{3}$, lime content, $\mathrm{MgO}, \mathrm{SO}_{3}, \mathrm{IR}$, free lime and LOI were determined [8-9] and compared with the standards. From the oxides of different elements, cement moduli i.e. MA, MS and LSF were also calculated. For the elemental analysis of cement X-Ray fluorescence (XRF) spectrophotometer, PW 2582/00 (Philips) and atomic absorption spectrometer (3300 Perkin Elmer), were used. For XRF, glass bead was made from the test material. For this purpose one gram of cement sample was mixed with six gram of dilithium tetraborate (Spectromelt ,Merck) in a platinum crucible to which $0.001 \mathrm{~g}$ of lithium bromide (Merck) was also added. The ingredients were thoroughly mixed. The crucible was heated in a muffle furnace at $1150^{\circ} \mathrm{C}$ for 15 min. Then the content of the crucible was transferred to a platinum mould inside the furnace and shaked to acquire the shape of the mould. The mould was cooled and the glass bead was obtained. After calibrating the XRF with certified standards, the sample bead was subjected for analysis in the machine and the result was obtained.

\section{Results and Discussion}

The percentages of major elements oxides of all the cement brands are given in Table 2. The comparisons of the major elements of the studied cement samples in oxide forms, like $\mathrm{SiO}_{2}, \mathrm{Al}_{2} \mathrm{O}_{3}, \mathrm{Fe}_{2} \mathrm{O}_{3}$ and $\mathrm{CaO}$ with the British standard specification are graphically shown in Figures 1-5.

\begin{tabular}{lrrrrrr}
\multicolumn{7}{l}{ Table 2: Chemical Composition of different brands of cement } \\
\hline$\%$ Oxides & Lucky & Askary & Bestway & Kohat & Mustehkam & Cherat \\
\hline $\mathrm{SiO}_{2}$ & 20.78 & 20.12 & 21 & 20.78 & 20.75 & 21.24 \\
$\mathrm{Al}_{2} \mathrm{O}_{3}$ & 5.11 & 5.53 & 5.04 & 5.81 & 5.3 & 5.56 \\
$\mathrm{Fe}_{2} \mathrm{O}_{3}$ & 3.17 & 3.47 & 3.24 & 2.99 & 4.26 & 3.24 \\
$\mathrm{CaO}$ & 60.89 & 62.2 & 61.7 & 62.18 & 61.24 & 63.53 \\
$\mathrm{MgO}$ & 3 & 1.71 & 2.56 & 1.52 & 2.03 & 0.93 \\
$\mathrm{SO}_{3}$ & 1.74 & 2.29 & 1.51 & 1.89 & 1.82 & 2.55 \\
& & & & & & \\
$\mathrm{LOI}$ & 2.31 & 1.45 & 1.83 & 2.31 & 1.53 & 1.24 \\
$\mathrm{IR}$ & 0.65 & 0.6 & 0.54 & 0.75 & 0.74 & 0.64 \\
Free lime & 1.02 & 1.14 & 0.98 & 0.68 & 0.85 & 0.55 \\
\hline
\end{tabular}

Figure 1 shows the comparison of silica in different brands of cement with British standards. British standards specify amounts of $\mathrm{SiO}_{2}$ in Portland cement within the range $21 \%$ to $22 \%$. It has been observed that Cherat Cement, Bestway Cement, Lucky Cement and Mustehkam cement qualify the standards while askary and Kohat cement have slightly lower silica than the standard i.e. 20.12 and 20.78 respectively.

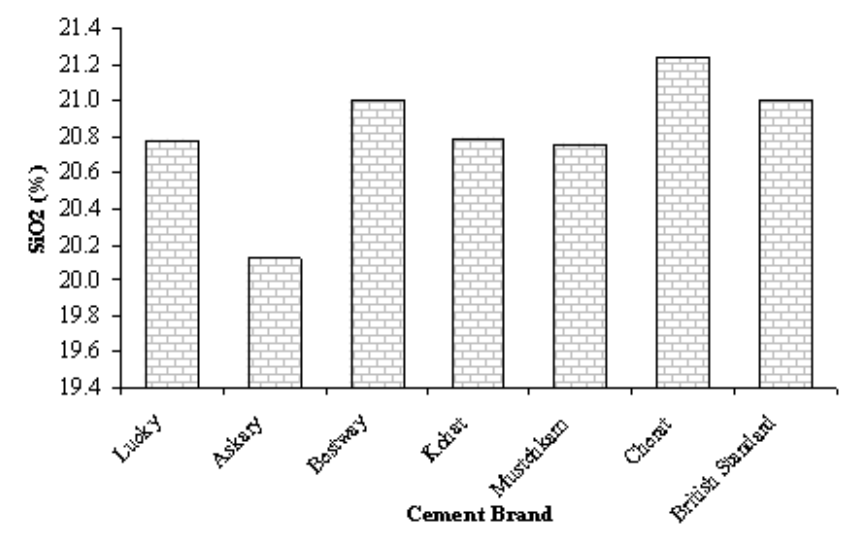

Figure 1: Comparison of Silicon Dioxide $\left(\mathrm{SiO}_{2}\right)$ in different brands of cements with British standard

The variation of aluminum oxide and iron oxide in different brands of cements available at the local market and its comparison with British standard are graphically shown in Figure 2 and 3 respectively. It was found that amount of $\mathrm{Al}_{2} \mathrm{O}_{3}$ in all the studied samples is lower than that of standard value $(6.00 \%)$ [7]. On the other hand the iron content in all the cement samples was found with in the specified limits except kohat cement $(2.99 \%)$. Amount of $\mathrm{CaO}$ as specified by the British standards should be within the range $60 \%$ to $67 \%$. All six brands of cement contain $\mathrm{CaO}$ within the specified limit that can be observed from Figure 4. 


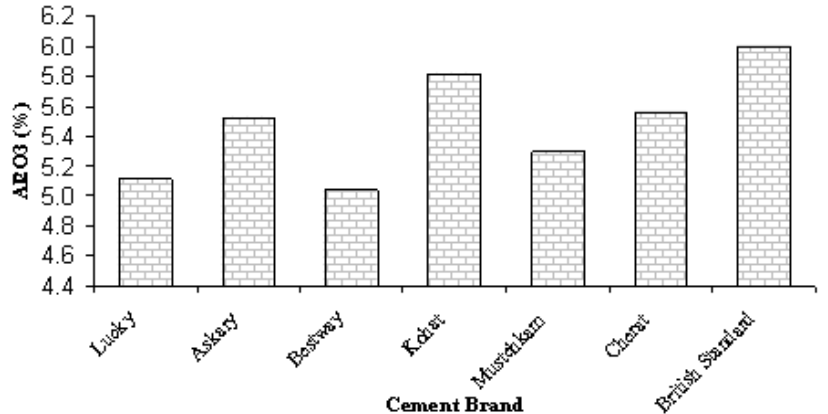

Figure 2: Comparison of Aluminum oxide $\left(\mathrm{Al}_{2} \mathrm{O}_{3}\right)$ in different brands of cements with British standard

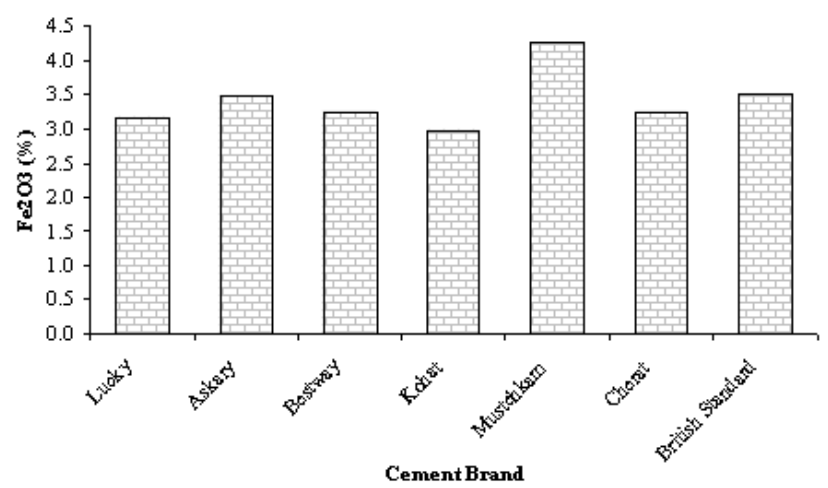

Figure 3: Comparison of Iron oxide $\left(\mathrm{Fe}_{2} \mathrm{O}_{3}\right)$ in different brands of cements with British standard

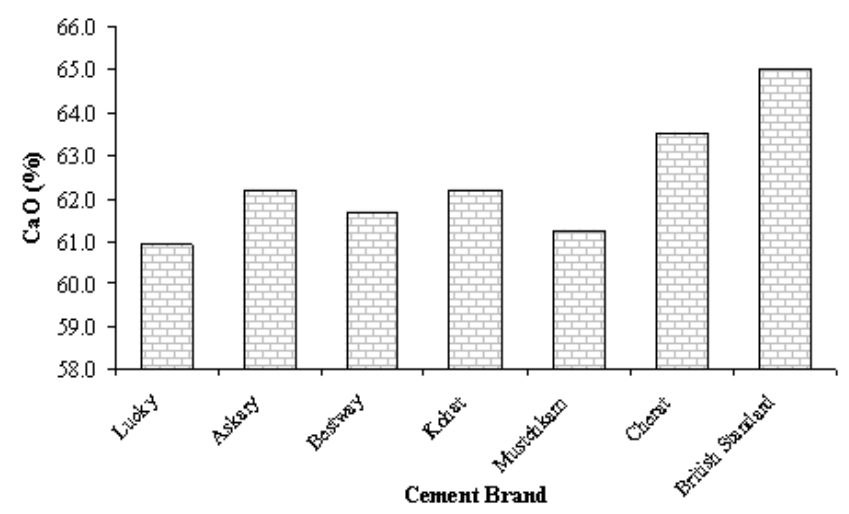

Figure 4: Comparison of Calcium oxide $(\mathrm{CaO})$ in different brands of cements with British standard
The proper lime content is limited due to the lower early strength produced when lime content of OPC is too low, and unsoundness when it is too high [8]. High lime content is associated with early strength where as, slightly lower content of lime favors ultimate strength which develops gradually over a long period of time [9, 10]. In order to increase the strength it is necessary to raise the lime content, or grind finer, or both. But higher temperatures are required to burn the high lime mixtures [11].

British standards specify amounts of $\mathrm{MgO}$ in OPC not more than $2.0 \%$. From Table 2 it is clear that only lucky and Bestway cements have higher $\mathrm{MgO}$ i.e. 3.00 and 2.56\% respectively. The remaining samples are having the Magnesium with in the specified limit.

The magnesia content is limited by the standard specifications not to exceed $2 \%$ because higher magnesia contents may be detrimental to the soundness of the cement, especially at late ages. Beyond that limit it appears in the clinker as free $\mathrm{MgO}$ (periclase). Periclase reacts with water to form $\mathrm{Mg}(\mathrm{OH})_{2}$, and this is the slowest reaction among all other hardening reactions. Since $\mathrm{Mg}(\mathrm{OH})_{2}$ occupies a larger volume than the $\mathrm{MgO}$ and is formed on the same spot where the periclase particle is located, it can split apart the binding of the hardened cement paste, resulting in expansion cracks commonly known as magnesia expansion $[8,9]$.

British standards specify the amount of $\mathrm{SO}_{3}$ in Portland cement to be $1.5-2.5 \%$. All the studied cement samples have Sulfuric anhydride with in the standard limits. Bestway cement has comparatively lower content of Sulfuric anhydride while Askary and cherat have very high $\mathrm{SO}_{3}$ content i.e. 2.29 and $2.50 \%$ respectively.

To control setting time effectively, cement needs a minimum amount of calcium sulfate, mostly in the form of gypsum added to the clinker.

On the other hand, the maximum allowable $\mathrm{SO}_{3}$-content in the cement to prevent sulfate expansion is established according to the various cement standards, between 1.5 and $2.5 \% \mathrm{SO}_{3}$. At the lowest limit imposed by cement standard specification, it could be possible that there is no sufficient scope left for an extensive sulfatizing of the alkalies [9, 11].

Insoluble residue of the studied cement samples is shown in Table 2. It is clear from the table that insoluble residue varies from $0.54-0.74 \%$. Insoluble residue is a noncementing material, which eventually exists in Portland cement. This residue material affects the properties of cement, especially its compressive strength. To control the non-cementing material in Portland cement, British standard allows the IR content to a maximum limit of $1.5 \%$. Insoluble residue of all the samples is compared with that of the British standard in Figure 5. It is evident from the figure that all the cement samples studied, have insoluble residue with the range.

There is no advantage in adding extra lime unless it is brought into combination with other constituents. If appreciable lime is left uncombined, it may cause expansion and cracking of the mortar or concrete [10]. Amount of free lime were found to vary in between 0.55 to $1.14 \%$ among the different brands of cements as shown in Table 2, which are con- 


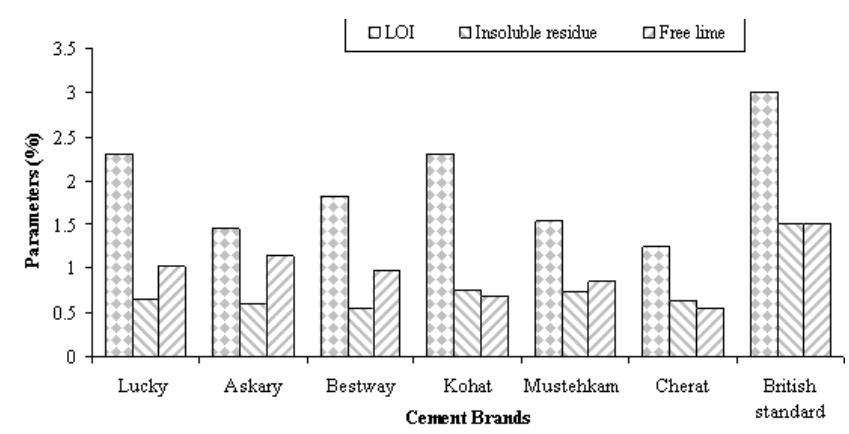

Figure 5: Comparison of LOI, Insoluble residue and free lime in different brands of cements with British standard

sidered with in the permissible limits according to British standards specification (1.5\%) If the lime content is fixed, and the silica becomes too high, which may be accompanied by a decrease in alumina and ferric oxide, the temperature of burning will be raised and the special influence of the high lime will be lost. If the lime content is too low, which means an increase in the alumina and ferric oxide; the cement may become quick-setting and contain a larger amount of alumina compounds, which appear to be of little value for their cementing qualities. Rapid setting is undesirable, and is not permitted by the standard specifications, because the cement sets up so rapidly that it cannot properly be worked in the forms before stiffening occurs [6].

A high LOI indicates pre-hydration and carbonation, which may be caused by improper and prolonged storage or adulteration of OPC during transport or transfer. All the cement samples were found to be competent with regard to maximum LOI limit of $4.0 \%$ as specified by the British Standard.

The cement moduli were calculated according to the following equations:

$$
\begin{gathered}
\text { Alumina modulus: } M A=\frac{\mathrm{Al}_{2} \mathrm{O}_{3}}{\mathrm{Fe}_{2} \mathrm{O}_{3}} \\
\text { Silica modulus: } M S=\frac{\mathrm{SiO}_{2}}{\mathrm{Al}_{2} \mathrm{O}_{3}+\mathrm{Fe}_{2} \mathrm{O}_{3}} \\
\text { Lime saturation factor: } L S F=\frac{\mathrm{CaO}}{2.8 \mathrm{SiO}_{2}+1.2 \mathrm{Al}_{2} \mathrm{O}_{3}+0.65 \mathrm{Fe}_{2} \mathrm{O}_{3}}
\end{gathered}
$$

The cement moduli along with the standards are graphically shown in Figure 6. The normal range of MA is 1.3-2.5. If it goes above 2.5 , viscous slag and high early strength occur and if it goes below 1.3, then fluid slag, low early strength and low heat of hydration occur. The usual range of MS is 23. For MS less than 2, burning become very easy but excessive liquid phase and low strength cement is obtained. On the other hand if the MS reaches up to 3, then the high strength cement is obtained, however the burning become very difficult. For MS more than 3, no clinkerization takes place at all. The normal range of LSF is $0.90-0.98$ but if it is 0.8 , it does not create any problem in cement manufacturing process and cement strength, however it should not go below 0.80 [11].
From Figure 6, it is clear that all the studied cement brands have MA, MS and LSF within the range.

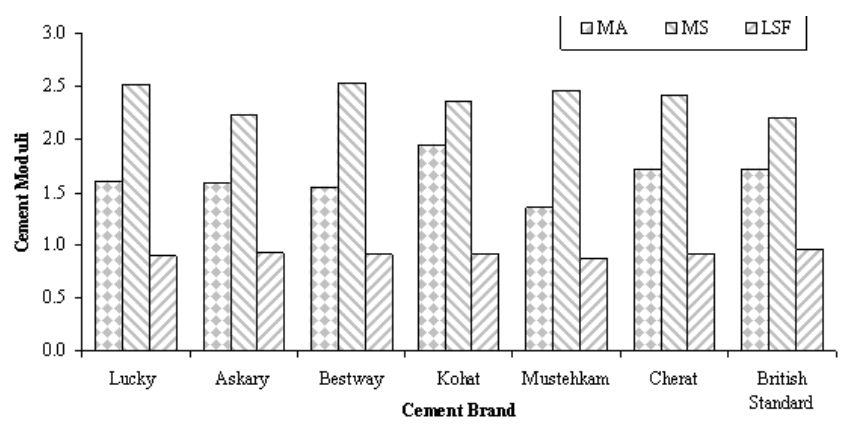

Figure 6: Comparison of cement moduli in different brands of cements with British standard

Four cement compounds like $\mathrm{C}_{2} \mathrm{~S}, \mathrm{C}_{3} \mathrm{~S}, \mathrm{C}_{3} \mathrm{~A}$, and $\mathrm{C}_{4} \mathrm{AF}$ which are responsible for the compressive strength are given below:

$\mathrm{C}_{3} \mathrm{~S}=\mathrm{Ca}_{3} \mathrm{SiO}_{5}$ or $3 \mathrm{CaO} \cdot \mathrm{SiO}_{2}$

$\mathrm{C}_{2} \mathrm{~S}=\mathrm{Ca}_{2} \mathrm{SiO}_{4}$ or $2 \mathrm{CaO} \cdot \mathrm{SiO}_{2}$

$\mathrm{C}_{3} \mathrm{~A}=\mathrm{Ca}_{3} \mathrm{Al}_{2} \mathrm{O}_{6}$ or $3 \mathrm{CaO} \cdot \mathrm{Al}_{2} \mathrm{O}_{3}$

$\mathrm{C}_{4} \mathrm{AF}=4 \mathrm{CaO} \cdot \mathrm{Al}_{2} \mathrm{O}_{3} \cdot \mathrm{Fe}_{2} \mathrm{O}_{3}$

The cement compounds have been calculated from the oxide composition of the cement using the Bogue formulae [6] as follows:

$\mathrm{C}_{3} \mathrm{~S}=4.071 \mathrm{CaO}-\left(7.6 \mathrm{SiO}_{2}+6.718 \mathrm{Al}_{2} \mathrm{O}_{3}+1.43 \mathrm{Fe}_{2} \mathrm{O}_{3}+\right.$ $2.852 \mathrm{SO}_{3}$ )

$\mathrm{C}_{2} \mathrm{~S}=2.867 \mathrm{SiO}_{2}-0.7544 \mathrm{C}_{3} \mathrm{~S}$

$\mathrm{C}_{3} \mathrm{~A}=2.56 \mathrm{Al}_{2} \mathrm{O}_{3}-1.69 \mathrm{Fe}_{2} \mathrm{O}_{3}$

$\mathrm{C}_{4} \mathrm{AF}=3.043 \mathrm{Fe}_{2} \mathrm{O}_{3}$

The values of cement compound are compared with those of British expressed in Figure 7. It is clear from the figure that cement compound of all are not significantly different from each other.

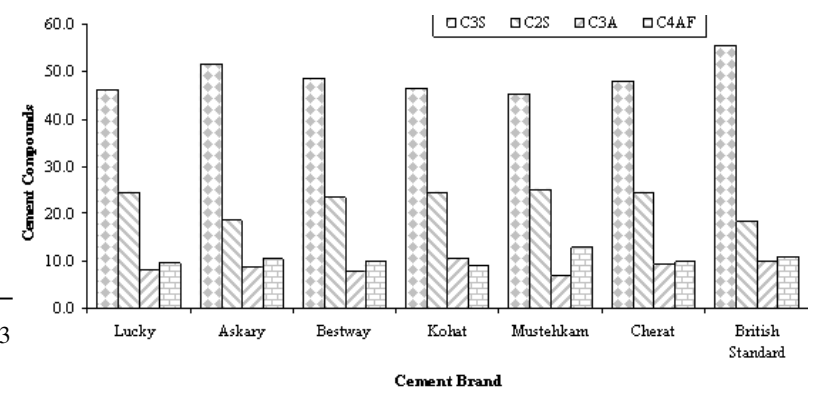

Figure 7: Comparison of cement potential in different brands of cements with British standard

Variations in chemical constituents affect the cement properties like, hardening/hydration, setting time, corrosion resistance, color, etc [9-11]. Possible and potential sources of error in testing might be grade of chemicals, and preparation of reagents, and accuracy of titrametric method (Classical analytical method) which depends on the technical experience of the investigator. Maximum temperature range of the furnace was $800^{\circ} \mathrm{C}$. But sometimes it was necessary to raise temperature up to $1000^{\circ} \mathrm{C}$. 


\section{Conclusion}

The ideal composition range of Portland cement is the problem of the research chemist. But out of the experience of observant operatives and the formulation of experimentally demonstrated principles by engineers and chemists, there have been established certain rather definite limitations in the feasible composition of a cement. Within those limits, experience has shown that the mixture behaves satisfactorily in the kilns and produces good cement; outside of those limits experience has shown that trouble in burning may result or that the cement may be of inferior quality.

\section{References}

[1] Austin G, Shreves Chemical Process Industries, McGraw Hill Book Company, Singapore, 5th edition, 1985

[2] Ali K, Amin N and Shah M, Physicochemical study of bagasse and bagasse ash from the sugar industries of NWFP Pakistan and its recycling in cement manufacturing, Journal of the chemical society of Pakistan, 2009. 31(3):pp. 375-378

[3] Amin N, Ali K and Shah M, Recycling of Bagasse ash in cement manufacturing and its impact on clinker potential and environmental pollution, Journal of the chemical society of Pakistan, 2009. 31(3):pp. 357-361

[4] Amin N, Ali K and Shah M, Raw Mix designing and clinkerization of High Strength Portland cement with Bagasse Ash and its impact on clinker moduli and fuel consumption, Journal of the chemical society of Pakistan, 2009. 31(3):pp. 370-374

[5] Amin N, Ali K and Shah M, Chemical study of limestone and clay for Cement Manufacturing in Darukhula Nizampur, District Nowshera, N.W.F.P., Pakistan, Chinese journal of geochemistry, 2008. 27(3):pp. 242-248

[6] Bye G, Portland cement composition, production and properties, Thomas Telford limited, London, 1999

[7] BSI, Specification for Portland Cement, 1991

[8] Taylor H, The Chemistry of Cements. Vol. 1, Academic Press, New York, 1964

[9] Pandey G and Shukla S, A Text Book of Chemical Technology.Vol. 1, Vikas Publishing House, New Delhi, 1980

[10] Furman N, Standard Method of Chemical Analysis, Van Nostrand Reinhold Co, New York, 6th edition, 1962

[11] Vogel A, A Text Book of Quantitative Inorganic analysis, The English Language Book Society and Longmans, Green \& Co. Ltd, 5th edition, 1989 